\title{
To Cope with the Spreading of Internet News Information Which Damages the Image of Public Security Organization
}

\author{
Jianwen Ma \\ Guangdong Police College \\ Guangzhou, China, 510232 \\ mmmkk@21cn.com
}

\author{
Dan Yi \\ Guangdong Police College \\ Guangzhou, China, 510232 \\ day199@21cn.com
}

\begin{abstract}
As the subject of law enforcement, the public security organization possesses the right of reputation. The situation of damaging the reputation of public security organization by Internet news information is as follows: fabricating, spreading and disseminating rumors, depreciating, insulting the reputation and defaming the image of the public security organization. The key solution is to allow citizens exercising the right of criticize instead of fearing the rumors, determine on handling intentional cases, building system of publicity on public security, as well as improving Netizen's cognition of public security.
\end{abstract}

\section{Keywords-internet; infringement; reputation; solution}

\section{Public Security Organization Possesses the LEGAL RIGHT OF REPUTATION}

In recent years, some individuals instigate the hatred of public security through Internet, which is forbidden by law. They create things out of nothing, slandering, attacking and defaming public security and police on duty. Their behavior has damaged the image and auth ority of public security, as well as the right of reputation.

The right of reputation is the right of citizen and legal entity, by which the object is the reputation of citizen and legal entity. As the subject of law enforcement, the public security has the right of reputation. The right of reputation is an important part of the right of personality by public security, which is conferred by law, necessary in safeguarding the right of independent legal entity and giving fair social evaluation, as well as the external image of public security. In Article 101 of the General Principles of the Civil Law in o ur country, the right of reputation and personal dignity of citizen and le gal entity are prot ected by law. That is, no matter by verbal, literate or Internet, slandering, defaming and dispraising in order to damage the public security organization, which brings damage to public security organization, are taken as the behavior of damaging reputation and had to bear legal liability. The important factor of damaging the right of reputation is the illegal behavior of doer, where the doer has spread false comment and information that are forbidden by law. In this regard, it contains as follows: (1) Fabricating, spreading and disseminating rumor. (2) Openly depreciating and insulting reputation and pers onal dignity of others, among which the comment is much ado about nothing; the insult is to spread and disseminate the existing defect and untruth in order to defame the reputation of others and to dishonor others. (2)The truth does existed but the words are insulting and slanderous in a subjective way, which results in bad impression of the victim by information receiver. According to the regulations mentioned above, though the problems reflected by the articles are generally verified, the contents have humiliated the public security organization and damaged its reputation, therefore, it should be taken as in fringing the right of reputation of the public security and police.

II. The Exsiting Legal Provisions And Problems of Public SECurity Organization ON Protecting Right OF REPUTATION

\section{A. Charge of Criminal Liability}

In Title 1 Article 243 of the Criminal Law: Whoever invents stories to implicate another person with the intention of having him investigated for criminal responsibility, if the circumstance is serious, shall be sent enced to fixed-term imprisonment of not more than three years, criminal detention or public surveillance; if the consequence is serious, he shall be sentenced to fixed-term imprisonment of not less th an 3 years but not more than 10 years. In Article 246: Whoever, by violence or other methods, publicly humiliates another person or invent stories to defame him, if the circumstance is serious, shall be sentenced to fixed-term imprisonment of not more than 3 years, criminal detention, public surveillance or deprivation of political rights. According to A rticle 246, humiliation and defamation are cases of private prosecution; however, there is "proviso" in this article: "except for where serious harm is done to public order or to the interest of the state". That is, the crime of defamation takes private prosecution as principle and public prosecution as exception. Only in the circumstance of "serious harm is done t o public order or to the in terest of the state", "invents stories to implicate another person" and "consequences are serious", can the private prosecution translate into public prosecution. Nevertheless, which kind of circumstance belongs to "serious harm is done to public order or to the interest of the state" has not set by the law. Among the cases of "conviction cause by words" in rec ent years, much of which are pu nishment and penalty by authority organization when some parties publish their speeches. For example, the case of arresting the reporter of magazine Legal Entity at the beginning o f year 2008, Xifeng county, Liaoning Province, the criminal case of libel in 
Cao County, Shandong Province in the year of 2009. In the cases, parties publish the ir speeches by incisive words to satirize the problems in the process of executing government affairs. The speeches are treated as accountability to rulers by citizen, in whi ch the contents are not violating the law. On account of the reality, if state violence is exercising frequently, especially by one party to defend its right, it will be taken as private use of state law, which, of course will lead to social response and controversy. As a r esult, frequently exercising state violence is not the best plan, except for several cases.

\section{B. Charge of Civil Liability}

In Article 120, if a citizen's right of personal name, portrait, reputation or honor is infringed upon, he shall have the right to demand that the infringement be stopped, his reputation be rehabilitated, the ill e ffects be eliminated and an ap ology be made; he may also demand compensation for losses. In Title 2, Article $1 \mathrm{O} n$ the Problems of Defining the Civil Right Infringement Spirit Damage Compensate Responsibility Explanation enacted by the Supreme People's Court in 2001: A violation of public interests, social morality, infringement of privacy or other int erests of personality, the victims can request the people's court for compensation of mental damages, the people's court shall accept it according to law. However, there is some difference between legal entity and natural person. As defined in On the Problems of Defining the Civil Right Infringement Spirit Damage Compensate Responsibility Explanation by the Supreme People's Court carried out in Mar. 10, 2001: when the natural person's personality rights are fringed, he have the right to request for compensation of moral damage, but it is not defined that the legal person can request for compensation of moral damage. When the public security organization's right of reputation is infringed, there are only five kinds of method including infringement cessation, reputation restoration, effect elimination, formal apology and compensation for property losses. Am ong the a foresaid five kinds of responsibility, several kinds can be requested at the same time but not only one kind. Right of reputation expresses as reputation and interest. It is not easy to $p$ rove to be infringed in reputation or lower in social evaluation because the public security organization is not business unit. One or two lawsuits may be easy, but it takes trouble and costs a lot to have more lawsuits, which is diff icult to handle for the grassroots units.

\section{Public Security Punishment}

In Article 42 of the Law of the PRC on Public S ecurity Administration: A person w ho commits any of the following acts shall be detained for not more than five days or be fined not more than $¥ 500$; if the circumstances are relatively serious, he shall be detained for not less than 5 day s but not more than 10 days and may, in ad dition, be fined not more than $¥ 500$ :

a) Threatening the personal safety of another person by writing letters of intimidation or by other means.

b) Openly humiliating another person or slandering another person by fabricating stories. c) Framing-up another person by fabricating stories in an attempt to make the person subject to criminal investigation or penalty for administration of public security.

d) Threatening, humiliating, beating up or retaliating against a witness or his close relatives.

e) Repeatedly dispatching pornographic, humiliating, intimidating or other information to disturb the normal life of another person.

f) Peeping, secretly taking photos eavesdropping, or spreading the privacy of another person.

The public security organization is the deci sive organization that conducts punishment to tho se who violate public security. However, if the party is the judicator itself, its credibility must be in doubt.

\section{SOLUTION}

\section{A. Allowing Citizens Exercising the Right of Criticize instead of Fearing the Rumors}

Freedom of speech protection is the basic political institution that is an indispensable social norm in modern society. According to Article 41 of the Constitution in our country: Citizen has the right to criticizing and giving opinions to government agencies and public servants, which means that the government agencies and public s ervants have the obligation to listen to critici sms and o pinions. The Constitution has imposed restriction on criticisms and opinions, where citizens cannot fabricate or distort the fact in ord er to carry out false accusation. The discussion participated by citizens is a part of the process of democracy, where improper words are in evitable. The public security organization can refute the criticisms and improper speeches through various ways. The authority of the public security is established in the eyes of citizens via it $\mathrm{s}$ activities step $\mathrm{b}$ y step, including credibility such as fair, impartial and conviction. The promotion of police authority not only relies on ex ercise of power according to law, but also on general acknowledgement of its activities by citizens. As a consequence, it is the s olid foundation to communicate and publicize completely to build citizens' belief on "for the sake of people, service foremost" and gain their approval of police. In the new situation of Internet harmony and stable society, by means of public relation, it is significant to deal with Internet information and establish police image.

\section{B. Determine on Handling Intentional Cases}

Law of the United States has not only defined high protection for freedom of the press but also restriction and punishment for abuse in freedom of the press. In the First Amendment of the sacred American Constitution: Congress shall make no law representing an establishment of religion, or prohibiting the free exercise thereof, or abridging the freedom of speech, or of the press, or the right of the people peaceably to assemble, and to petition the Government for a redness of grievance. Generally, in the United States, only in three kinds of circumstance can the press be forbidden which is called "Three Exceptions": against national security, obscenity, incite violence to topple down the gov ernment. Before 1964, the United States had practiced strict liability on the press, namely, 
so long as the accuser proves that the report has iss ued publicly and referred to the victim explicitly that resulted in harm", the press had to assume responsibility. In 1964, the case "New York Times' appeal to Sullivan" had set up a new condition, that is, the accuser had to prove that the press knows the false information in advance but still adds malevolence to the truth and reports it in a false way. Sullivan is a director of state police, although he wins all the lawsuits in the state courts and judged for compensation of one million USD, he fails in the Su preme Court because the nin e justices apply "truth malevolence" principle. Afterwards, the Supreme Court applies "truth malevolence" to public servants and those who publish issues with the intention of guaranteeing freedom of speech to the hit and promoting public discussion. Nevertheless, it leads to abuse in freedom of speech. In 1969, Guez was att acked as acco mplice by the American Opinion because of a criminal case. The Supreme Court considered the case was not in the condition of "truth malevolence". Hence, the judicial applies "truth malevolence" principle when it refers to "public figure" or "public interest".

To reflect social life, and to castigate social evils as well as to express opinions constitute the important spiritual social life, which should be backed and protected by law. However, if the Internet is used in tentionally to defame the image of public security organization and thus lead to da mage, legal liability should be assumed. The public secu rity organization should use law to safeguard its rights. A system of strict enquiry and punishment together with clarify in time should be established. The one who post the speech should be inspected in real his identity. The public security organization should clarify the reality through media. Meanwhile, measures should be taken to prevent false speech from spreading and $\mathrm{o}$ intercept harmful information for the sake of lower influence.

\section{Establish System of Internet Publicity andCommunication on Public Security, Improve Cognition on Public Security among Netizens}

The collective action of Internet is based on co mplete reliance among participants, but from where can we attain network reliance that is $r$ are in today's society? The author considers it as a rule of "tit for tat" that function. That is, if mutual reliance is established at the very beginning, then both parties will choose to trust each other. In the opposite, if both parties choose not to trust each other, then there will be no mutual reliance. Therefore, the public security organization should actively build public security image system together with the Internet in order to improve the recognition among netizens. The loyalty and responsibility the public security have and the hard wo rk they do to c rack down on criminal offence should be presented to netizens to enha nce their recognition. The public secu rity organization should build a platform of communication between public security organization and net izens, where the public security organization can publicize their perf ormance. The public security organization should know netizens' reaction and explain their questions as well as discuss events and cases in a reason way. Work should be done to win support and understanding among netizens in a harmonious way.

\section{REFERENCES}

[1] Jiang Yaping,"Computer Culture and Cultural Reorganization"[A], "Network Communication and Social Development"[M], in press.

[2] Zhu Xiaojuan, DaiZhiqiang, "Peronal Right-Principle, Rules and Cases", in press.

[3] "Date and Information for Safeguard Legal Rights", Pu blic Seciruty Department of Gangdong Province, 2008-2009.

[4] “American Journalists' Legal Handbook on H ow to Protect Your Rights", Transl.Sun Ying, in press. 